African Crop Science Journal by African Crop Science Society is licensed under a Creative Commons Attribution 3.0 Uganda License. Based on a work at www.ajol.info/ and www.bioline.org.br/cs DOI: http://dx.doi.org/10.4314/acsj.v25i3.4

\title{
NUTRITIONAL COMPOSITION OF A FULL DIALLEL-CROSSED FORAGE PEARL MILLET OF NIGERIA ORIGIN
}

\author{
O.O. LAWAL \\ Department of Crop Production, College of Agriculture, Kwara State University, Malete, Ilorin, Nigeria \\ Corresponding author: oluwatosin.lawal@kwasu.edu.ng
}

(Received 9 September, 2016; accepted 3 August, 2017)

\begin{abstract}
The productivity of local cattle depends mainly on the quality of forage they consume, the search of which induces conflicts between herdsmen and farmers. The objective of this study was to evaluate the nutritional quality of 'maiwa' Pennisetum glaucum, for forage, in Ibadan, Nigeria. Three inbred lines, namely, 25-2, 28-1 and 94-2 were each sown in three rows in 2009. The inbred lines were crossed in all combinations including reciprocals, to generate six hybrids and three inbred lines. The hybrids and their inbred lines were then evaluated. 'Maiwa' plants were harvested by cutting at $30 \mathrm{~cm}$ above the ground level, at six weeks after sowing. The plants were allowed to regrow for 7 to 8 weeks to reach booting stage, and samples were collected for proximate analysis. The inbred lines had generally higher dry matter DM content (36.02\%) than the hybrids (33.39\%). Also, leaf had higher DM (29.67 to $41.11 \%$ ) than the stem (17.59-24.75\%), which was above $20 \%$ benchmark. Crude protein (CP) level ranged from 8.76 to $10.66 \%$, which was above the $7 \%$ critical level, below which intake declines. Ca: $\mathrm{P}$ ratio ranged from 1: 0.89 to $1: 1.58$ in $94-2 \times 25-2$ and 28-1 $\times 94-2$ respectively in 'maiwa'. The Ca: $\mathrm{P}$ ratios reflect the higher content of $\mathrm{P}$ in all the lines, except $94-2 \times 25-2$ hybrid. This shows that the nutritional quality of 'maiwa' as forage is satisfactory for animal dietary requirement, except for lactating animal where supplementary $\mathrm{CP}$ might be provided.
\end{abstract}

Key Words: Crude protein, hybrids, proximate analysis

\section{RÉSUMÉ}

La productivité des bovins locaux dépend principalement de la qualité du fourrage consommé, dont la quête crée de conflits entre les bergers et les agriculteurs. L'objectif de cette étude était d'évaluer la qualité nutritionnelle du 'maiwa' Pennisetum glaucum, pour le fourrage, à Ibadan, Nigéria. Trois lignées inbreds ; à savoir, 25-2, 28-1 et 94-2 était chacune semée en trois lignes en 2009. Les lignées inbreds étaient croisées dans toutes les combinaisons y compris les réciproques ; pour générer six hybrides et trois lignées consanguines. Les hybrides et leurs lignées inbreds étaient donc évalués. Les plants de 'Maiwa' étaient récoltés par coupe à $30 \mathrm{~cm}$ du niveau du sol, à six semaines après semis. Les plants étaient laissés pour donner des repousses pendants 7 à 8 semaines pour atteindre la période de démarrage, et des échantillons étaient collectés pour des analyses immédiates. Les lignées consanguines avaient généralement grande teneur en matière sèche DM $(36,02 \%)$ que les hybrides $(33,39 \%)$. Aussi, les feuilles avaient une grande GM $(29,67$ à 41,11\%) que la tige $(17,59-24,75 \%)$, qui était au-dessus de $20 \%$ de référence. Le niveau de la protéine brute $(\mathrm{CP})$ variait entre 8,76 à $10,66 \%$ qui était au-delà du niveau de référence de 7\%, en deçà duquel la prise est impossible. Le rapport $\mathrm{Ca}: \mathrm{P}$ variait entre $1: 0,89$ à $1: 1,58$ en 94$2 \times 25-2$ et 28-1 × 94-2 respectivement dans 'maiwa'. Les rapports $\mathrm{Ca}: \mathrm{P}$ reflètent la plus grande teneur en $\mathrm{P}$ dans toutes les lignées, sauf l'hybride 94-2x 25-2. Ceci montre que la qualité nutritionnelle de 'maiwa' comme fourrage 
est satisfaisante pour les besoins alimentaires des animaux, sauf les animaux nourriciers où des suppléments $\mathrm{CP}$ doivent être apportés.

Mots Clés: Analyses immédiates, hybrides, protéine brute

\section{INTRODUCTION}

The genus, Pennisetum, is dispersed all over the tropics and subtropics of the world, with about 140 species belonging to the grass family - Poaceae being documented (Upadhyaya et al., 2008). One African species, Pennisetum glaucum (L.), has been domesticated as pearl millet. It is a foremost cereal grown on about 25 million hectares, principally for grain production in the arid and semi-arid tropical (SAT) regions of Africa and Asia (Rai et al., 2008), where it serves as a staple (Vetriventhan et al., 2008). Pearl millet production is concentrated in developing countries, which account for over $95 \%$ of the global production (Basavaraj et al., 2010). It is an important staple cereal in the drier parts of northern Nigeria, but utilised as forage in subtropical regions. Aken'Ova (1976) established that pearl millet could be grown for forage at Ibadan in the lowland forest zone where it is not normally cultivated and where rainy season lasts eight or more months.

Pearl millet grows well in marginal soils (Newman et al. 2010), where fodder crops are often cultivated. It has great yield potential and can produce more forage than either sorghum (Sorgum bicolor) or maize (Zea mays) (Kevin and Blaine, 1991). Pearl millet is extensively grown for forage as hay, silage, green-chop, and pasture in the southern U.S.A. (Lang, 2001) because of its drought tolerance and ability to produce grain under minimal inputs (Hanna and Cardona, 2001).Pearl millet is desirable for forage because it has high forage yield, heavy tillering ability, leafiness and succulent stems (Maiti and Rodriguez, 2010). This accounts for its superior forage quality, acceptability and intake by animals. The importance of chemical (crude protein, fibre, $\mathrm{N}$-free extract) and essential minerals such as calcium (Ca), phosphorus $(\mathrm{P})$, magnesium $(\mathrm{Mg})$, potassium $(\mathrm{K})$ in animal health and performance, milk and meat production is beyond emphasis (Cecelia et al., 2007). Cecelia et al. (2007) accentuated the importance of trace minerals: (sodium $(\mathrm{Na})$, manganese $(\mathrm{Mn})$, irons $(\mathrm{Fe})$, copper $(\mathrm{Cu})$ and zinc $(\mathrm{Zn})$ in cattle feed and production.

Although extensive trials have been conducted on agronomic traits of pearl millet, its response to fertiliser rates (Shahin et. al., 2013), yield potential of grain and forage potential of 'maiwa' type pearl millet in particular at Ibadan (Aken'Ova 1976), there is paucity of information on the nutritional quality of 'maiwa'. 'Maiwa', the pearl millet type used in this study is an indigenous, shortday, photoperiod-sensitive and late maturing type (Aken'Ova, 1976). The objective of this study was to assess the nutritional quality of 'maiwa' inbred lines and hybrids based on its chemical and mineral composition.

\section{MATERIALS AND METHODS}

Study site. The experiment was conducted in the Kwara State University, Agronomy Department garden $\left(7^{\circ} 26^{\prime} \mathrm{N}\right.$ and $\left.3^{\circ} 54^{\prime} \mathrm{E}\right)$ at $218 \mathrm{~m}$ above the sea level within the rain forest zone of Nigeria. The physical and chemical properties of the experimental site are given in Table 1. Rainfall at the site is bimodal, reaching up to 8 months. Treatments were the inbred lines and corresponding hybrids from diallel cross namely: $25-2,28-1,94-2,25-2$ x 28-1, 25-2 x 94-2, 94-1 x 25-2, 28-1 x 94-2 and 94$2 \times 28-1$

The experiment was laid down in a randomised complete block design, with three replications. Three promising inbred lines of 'maiwa' pearl millet, namely $25-2,28-1$ and 94-2, developed from several years of 
TABLE 1. Chemical and physical properties of the experimental site

\begin{tabular}{lr}
\hline Soil characteristic & Value \\
\hline $\mathrm{pH}\left(\mathrm{H}_{2} \mathrm{O}\right) 1: 1$ & 6.60 \\
Organic carbon $\left(\mathrm{g} \mathrm{kg}^{-1}\right)$ & 12.16 \\
Total nitrogen $\left(\mathrm{mg} \mathrm{kg}^{-1}\right)$ & 0.75 \\
Available phosphorus $\left(\mathrm{mg} \mathrm{kg}^{-1}\right)$ & 12.51 \\
Exchangeable acidity $\left(\mathrm{cmol} \mathrm{kg}^{-1}\right)$ & 0.50
\end{tabular}

Exchangeable bases (cmol kg-1)

$\begin{array}{ll}\mathrm{K}^{+} & 0.30 \\ \mathrm{Na}^{+} & 0.34 \\ \mathrm{Ca}^{2+} & 2.88 \\ \mathrm{Mg}^{2+} & 0.91\end{array}$

Micro nutrients $\left(\mathrm{mg} \mathrm{kg}^{-1}\right)$

$\begin{array}{lr}\mathrm{Mn}^{2+} & 74.70 \\ \mathrm{Fe}^{2+} & 30.90 \\ \mathrm{Cu}^{2+} & 1.31 \\ \mathrm{Zn}^{2+} & 17.80\end{array}$

Particle size $\left(\mathrm{g} \mathrm{kg}^{-1}\right)$

Textural class (USDA) Loamy sand

a Soil was sampled at $15 \mathrm{~cm}$ depth; USDA= United States Department of Agriculture

inbreeding, top crossing and evaluation were obtained from the breeding unit of the Agronomy Department of the University of Ibadan in Nigeria. The three inbred lines were crossed in all possible combinations, following Griffing (1956), to generate $F_{1}$ hybrids and their reciprocal. The inbred parents were also included in the evaluation, using Griffing model 1. Three rows of each of the inbred lines were sown at a spacing of $90 \mathrm{~cm} \times 90 \mathrm{~cm}$, in a staggered manner. The pollen parents were planted three days earlier since millet is protogynous and self-fertilising. The 'head' of the 'maiwa' pearl millets were bagged and clipped prior to anthesis, in the morning, and pollen was collected the next day at about 10:00 am after sun rise. This allows for free flow of pollen.
Pollen was collected from a particular row of inbred line 25-2 and dusted on 28-1. The reciprocal crosses were obtained by changing previous pollen parents to female parents. This procedure was repeated for all inbred lines. In each case, the bags were labeled appropriately and dated. The seeds of each of the crosses were harvested separately, threshed and stored.

\section{$F_{1}$ hybrids, their reciprocals and parents}

Field establishment and management. The experimental seed beds were prepared manually to allow for easy germination of the small grains of pearl millet. Each inbred and hybrid was sown in single row plots, laid out in randomised complete block design, with three replicates. Each plot was $1.5 \mathrm{~m}$ long with a $30 \mathrm{~cm}$ gap between plots in the same block; while blocks were $90 \mathrm{~cm}$ apart. Sowing was by hand-drilling at the rate of $10 \mathrm{~kg} \mathrm{ha}^{-1}$ on 16 June, 2010 when rain was stable. Seeds had been dressed with triazoles before sowing. Owing to insufficiency of seeds of 94-2 $\times 28$ 1 , it was only sown in blocks I and II. This was taken into consideration during statistical analysis as missing plots.

Weeds were effectively controlled through hand-weeding and NPK 15-15-15 fertiliser was applied at $100 \mathrm{~kg} \mathrm{~N} \mathrm{ha}^{-1}$ in split dose of $50 \mathrm{~kg}$, three weeks after sowing, and $25 \mathrm{~kg}$ after each of the first and second harvests. The regrowth after the second harvest was allowed to boot stage, i.e. when $50 \%$ of the plants in a plot had reached booting stage. This is the stage when millet is harvested for silage production. The harvested herbage was separated into leaf and stem portions. The leaf portion was composed of lamina; while the stem portion included leaf sheath and its stem.

Chemical composition of 'maiwa' pearl millet. Boot stage was reached 20 weeks after sowing (WAS), and representative samples of each of the hybrids and inbred lines were taken from block II with both block I 
and III serving as border row. The samples were oven-dried at $70^{\circ} \mathrm{C}$ to a constant weight and, thereafter, milled to pass through $1 \mathrm{~mm}$ sieve. A portion of the sample was used for proximate analysis to determine: crude protein (CP), ash, crude fibre (CF), ether-extract (EE) and $\mathrm{N}$-free extract (NFE) contents according to the methods of the Association of Official Analytical Chemists, AOAC (2016).

Mineral composition of 'maiwa' pearl millet. The other portion of the dried milled samples were subjected to wet digestion oxidation in order to determine the mineral content of the resulting solution measured through atomic absorption spectrophotometer (AOAC, 2016). The following essential and trace minerals, $\mathrm{Ca}, \mathrm{P}, \mathrm{Mg}, \mathrm{K}, \mathrm{Na}, \mathrm{Mn}, \mathrm{Fe}, \mathrm{Cu}$ and $\mathrm{Zn}$, were determined.

\section{RESULTS AND DISCUSSION}

Leaf and dry matter (DM) content. Inbred 28-1 had the highest proportion of leaf on dry weight $(77 \%)$ basis (Table 2). All hybrids with 28-1 as female parent had higher proportions of leaf than hybrids without 28-1 as seed parent. Thus, 28-1 $\times$ 94-2 had $75 \%$ on dry basis; while $28-1 \times 25-2$ had $76 \%$. Inbred 94-2 had the lowest proportion of leaf. Generally, these results confirmed the high leaf to stem ratio and leafiness of pearl millet (Kevin and Blaine, 1991; Newman et al., 2010). The proportion of leaf observed in the present study is in consonance with the values of 67 and $63 \%$ reported by Ogbaji and Aken'Ova (1995) for 'maiwa' $\mathrm{x}$ 'maiwa' and 'maiwa' $\mathrm{x}$ 'dauro' crosses, respectively; implying that the assessed 'Maiwa' was leafy.

The inbred lines had generally higher DM content $(36.02 \%)$ than the hybrids $(33.39 \%)$ (Table 2). Also, leaf DM content ranged from 29.67 to $41.11 \%$, and was higher than stem DM content (17.59-24.75\%) in all hybrids and inbred lines. This indicates lower moisture level in the leaf compare to stem. Aguiar et al.
(2006) and Fulkerson et al. (2008) reported $19.4 \%$ in pearl millet. Obok et al. (2012), who harvested pearl millet at an early stage, reported DM of $18 \%$ in an interspecific hybrid between maiwa and elephant grass. Overall, the DM content of both the leaf and stem were above $20 \%$, the minimum DM content considered suitable for animals with high dietary requirement, like cattle (Nutrient Requirements of Dairy Cattle (NRDC), 2001). The relatively high DM content at boot stage could be as a result of water decline, associated with aging i.e. maturity (Maria et al., 2010). The higher the DM the less succulent the forage tends to be, thus negatively imparting palatability and digestibility (Schank et al., 1993; Wadi et al., 2004). However, 'maiwa' with high DM is of essence in quality silage production (Aganga and Tshwenyane, 2003).

Chemical composition. Chemical analysis of 'maiwa' cut at boot stage revealed that the hybrids and inbred lines had crude protein (CP) contents between 8.76 and $10.66 \%$ (Table 2). These were above $7 \%$, the critical level below which intake of tropical forage declines significantly (NRDC, 2011). Inbred line 25-2 had the highest $\mathrm{CP}$ of $10.66 \%$; while $\mathrm{F}_{1}$ hybrid 28-1 $\times 94-2$ had a CP of $10.58 \%$ and recorded the highest level among the hybrids.

The CP level (8.76 to $10.66 \%$ ) obtained in the present study are lower than the $\mathrm{CP}$ of 17.41 and $15.78 \%$ reported by Aken'Ova (1976), when 'maiwa' was harvested after 4 and 5 weeks regrowth, respectively. The difference could be due to the latter harvesting age and the subsequent decline in $\mathrm{CP}$ that accompanies aging (Erarome, 2005; Maria et al., 2010). The CP values of the inbred lines and hybrids also fell within the acceptable levels for forage pearl millet (Ogbaji and Aken'Ova, 1995). For animals such as dairy cattle with higher CP requirements, pearl millet at earlier growth stages of 8 to 12 weeks would be needed. It may be noted that when inbred 281 served as female parent in the hybrids, the 
TABLE 2. Dry matter (DM) content, proportion of leaf and chemical composition of 'maiwa' at boot stage harvest in Ibadan, Rainforest zone of Nigeria

\begin{tabular}{|c|c|c|c|c|c|c|c|c|c|}
\hline Lines & DM Leaf & DM Stem & Leaf fresh & Leaf dry & $\mathrm{CP}$ & $\mathrm{CF}$ & $\mathrm{EE}$ & Ash & NFE \\
\hline$F_{1}$ hybrids & --- & --- & --- & --- & $-\%-$ & - & -- & -- & ---- \\
\hline $25-2 \times 28-1$ & 29.67 & 19.70 & 45.00 & 68.00 & 8.76 & 34.28 & 3.97 & 10.57 & 32.89 \\
\hline $28-1 \times 25-2$ & 30.00 & 17.59 & 44.00 & 76.00 & 9.65 & 32.79 & 4.25 & 10.96 & 32.97 \\
\hline $25-2 \times 94-2$ & 30.77 & 17.94 & 38.00 & 66.00 & 10.47 & 31.54 & 3.89 & 11.35 & 33.19 \\
\hline $94-2 \times 25-2$ & 37.73 & 20.42 & 31.00 & 56.00 & 9.28 & 32.59 & 4.11 & 11.14 & 32.52 \\
\hline $28-1$ x 94-2 & 41.11 & 24.75 & 45.00 & 75.00 & 10.58 & 30.34 & 4.58 & 10.89 & 33.62 \\
\hline $94-2$ x $28-1$ & 31.07 & 19.09 & 42.00 & 69.00 & 9.89 & 32.28 & 3.75 & 10.67 & 34.20 \\
\hline $\mathrm{F}_{1}$ average & 33.39 & 19.92 & 40.83 & 68.33 & 9.77 & 32.30 & 4.09 & 10.96 & 33.23 \\
\hline \multicolumn{10}{|l|}{ Inbreds } \\
\hline $25-2$ & 37.22 & 19.77 & 41.00 & 77.00 & 10.66 & 30.38 & 4.67 & 11.08 & 33.62 \\
\hline $28-1$ & 32.5 & 20.20 & 48.00 & 77.00 & 8.95 & 33.37 & 4.06 & 11.24 & 33.20 \\
\hline $94-2$ & 38.33 & 22.80 & 36.00 & 61.00 & 10.39 & 30.47 & 4.82 & 11.44 & 32.46 \\
\hline Inbred average & 36.02 & 20.92 & 41.67 & 71.67 & 10.00 & 31.41 & 4.52 & 11.24 & 30.09 \\
\hline Overall average & 34.71 & 20.42 & 41.25 & 70.00 & 9.85 & 31.99 & 4.23 & 11.06 & 33.19 \\
\hline $\mathrm{CV}(\%)$ & 12.60 & 11.19 & 12.90 & 10.85 & 7.40 & 4.40 & 8.80 & 2.70 & 1.70 \\
\hline
\end{tabular}


$\mathrm{CP}$ content was higher than when it was the pollen parent, reflecting the presence of maternal effect for $\mathrm{CP}$ in 'maiwa'.

Although $\mathrm{CP}$ is a critical quality parameter in silage production, crude fibre (CF), ether extract (EE), ash and nitrogen free extract (NFE) are also important (Comerford, 2017). The CF ranged from 30.34 to $34.28 \%$ in $28-1$ $\times 94-2$ and $25-2 \times 28-1$, respectively. This range is close to $29-34 \% \mathrm{CF}$ reported by Erarome (2005) and NRDC (2011) and it is within the desirable limits (NRDC (2011). The $\mathrm{CF}$ values were higher than the $\mathrm{CF}$ of 26.06 and $27.96 \%$ (Aken'Ova, 1976) of open pollinated 'maiwa' after 4 and 5 weeks regrowth, respectively. The higher $\mathrm{CF}$ at boot stage in the present study could be attributed to increased lignification that accompanies physiological maturity in plants (Erarome, 2005; Maria et al., 2010).

The EE values ranged between 3.75 and $4.82 \%$ in $94-2 \times 28-1$ and $94-2$, respectively (Table 2). Inbred line 94-2 had the highest EE (4.82\%) among all the entries; while 28-1 had the least EE (4.06\%), among the inbred lines. 28-1 $\times 94-2$ had the highest EE (4.58\%) among the $\mathrm{F}_{1}$ hybrids; while its reciprocal, $94-2 \times 28$ 1 had the least EE $(3.75 \%)$.

The ash content of inbred lines and their hybrids ranged from 10.67 to $11.44 \%$ in $94-2$ $\times 28-1$ and 94-2, respectively. Among the hybrids, $25-2 \times 94-2$ had the highest ash content $(11.35 \%)$; while $94-2 \times 28-1$ had the least. The ash content provides an indication of the mineral content such $\mathrm{Na}, \mathrm{P}, \mathrm{K}, \mathrm{Ca}$ and $\mathrm{Mg}$ of the forage.

The NFE content ranged from 32.46 to $34.20 \%$ in $94-2$ and $94-2 \times 28-1$, respectively (Table 2). This is lower than $41-52 \%$ range reported by Erarome (2005), reflecting genetic and environmental differences.

Mineral content at booting stage. Table 3 shows that mineral content was variable. The $\mathrm{Ca}$ : $\mathrm{P}$ ratio ranged from 1: 0.89 for $94-2 \times 25$ 2 to 1 : 1.58 for $28-1 \times 94-2$ in 'maiwa' inbreds and hybrids. $\mathrm{Ca}$ : $\mathrm{P}$ ratios reflected the higher content of $\mathrm{P}$ in all the lines except $94-2 \times 25$ -

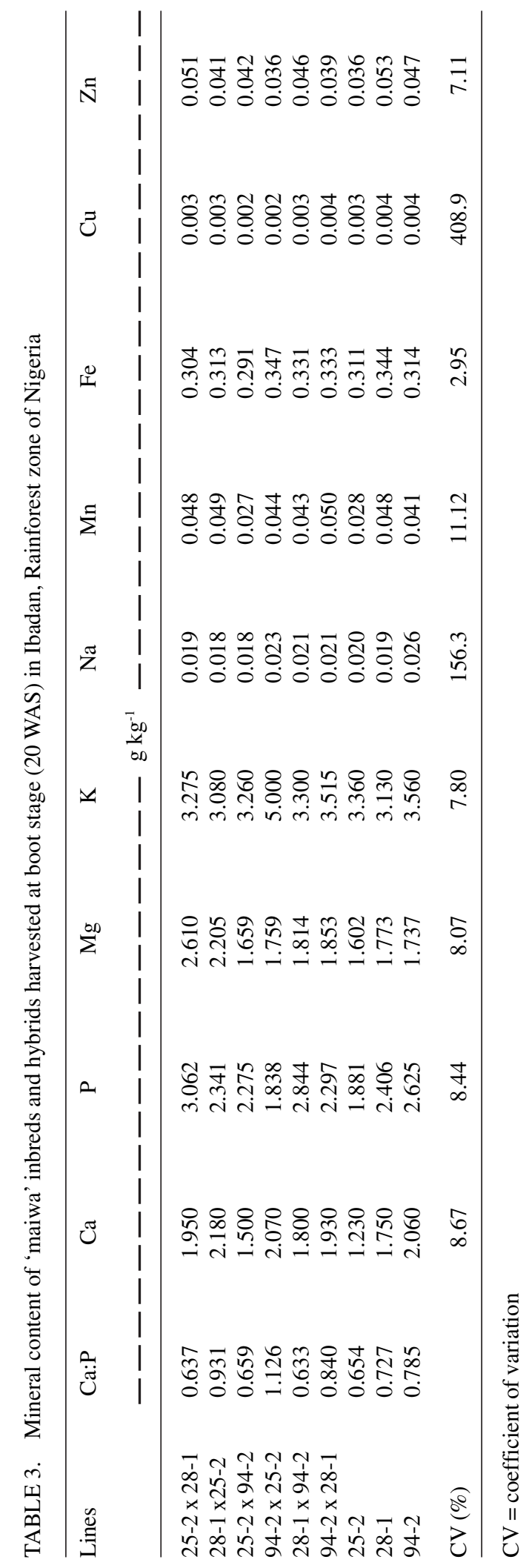


2 hybrid. The ratios do not conform to the desired 1: 1 to 2: 1 ratios for ruminant nutrition as in tropical forage (Rubanza et al., 2005). A balanced ratio between $\mathrm{Ca}$ and $\mathrm{P}$ is critical in forage breeding as it affects important physiological processes in animals (Comerford, 2017).

The $\mathrm{P}$ content ranged from 1.838 to 3.062 $\mathrm{g} \mathrm{kg}^{-1}$, with 25-2 $\times 28-1$ having the highest $\mathrm{P}$ content $\left(3.062 \mathrm{~g} \mathrm{~kg}^{-1}\right)$. Also, Ca content of 'maiwa' ranged from 1.230 to $2.180 \mathrm{~g} \mathrm{~kg}^{-1}$, with 28-1 $\times 25-2$ having the highest $\mathrm{Ca}$ content $\left(2.180 \mathrm{~g} \mathrm{~kg}^{-1}\right)$. The $\mathrm{Ca}$ and $\mathrm{P}$ content of both the hybrids and their inbred lines were well above 0.32 and $0.17 \%$, recommended for maintenance of domestic livestock, as well as $0.16-0.60 \% \mathrm{Ca}$ and $0.16-0.43 \% \mathrm{P}$ for beef and dairy cattle (Rubanza et al., 2005). Ca and P variations among the inbred lines and their hybrids were relatively low $(\mathrm{CV}=8.67$ and $8.44 \%$, respectively).

The Mg content fell between 1.602 and $2.610 \mathrm{~g} \mathrm{~kg}^{-1}$, with $25-2 \times 28-1$ having the highest (2.610 $\mathrm{g} \mathrm{Mg} \mathrm{kg}^{-1}$ (Table 3). The $\mathrm{Mg}$ (1.602 to $2.610 \mathrm{~g} \mathrm{~kg}^{-1}$ ) and $\mathrm{Ca}$ (1.230 to 2.180 $\mathrm{g} \mathrm{kg}^{-1}$ ) contents in the present study were much higher than the dietary $\mathrm{Mg}$ and $\mathrm{Ca}$ requirements of beef and dairy cattle which are between 0.4 and $1.8 \mathrm{~g} \mathrm{~kg}^{-1}$ (Makeri and Ugherughe, 1992). Also, the variability among inbred lines and their hybrids followed similar trends as $\mathrm{P}$ and $\mathrm{Ca}$, with $\mathrm{CV}$ value of $8.07 \%$.

The Na concentration ranged from 0.018 to $0.026 \mathrm{gkg}^{-1}$ (Table 3 ), which meets the levels recommended for beef cattle $(0.06-0.10 \%$; NRC, 1984), dairy cattle (0.18\%; NRC, 1978, Rubanza et al., 2005) and those for sheep (0.04-0.10\%; NRC 1976). Lactating dairy cows could, however, be given salt supplement if only fed with 'maiwa' alone as it might not meet its nutritional needs.

\section{CONCLUSION}

The study indicates that nutrient composition of maiwa is above the nutritional requirements of livestock, though, mild supplements should be added especially for lactating animals.

\section{ACKNOWLEDGEMENT}

I appreciate the financial and technical support provided by Late Professor M.E Aken'Ova of the Agronomy Department, University of Ibadan, Nigeria for this research.

\section{REFERENCES}

Aganga, A.A. and Tshwenyane, S.O. 2003. A review of the potential of buffel grass (Cenchrus ciliaris) and napier grass (Pennisetum purpureum) for livestock feeding in Botswana. Journal of Agricuture 12:15-23.

Aguiar, E.M. de, Lima, G.F. da C, Santos, M.V.F. dos, Carvalho, F.F.R. de, Medeiros, H.R., Maciel, F.C. and Januario, A.C.C. 2006. Intake and apparent digestibility of chopped grass hays fed to goats. Revista Brasileira de Zoologia 35(6):2219-2225.

Aken'Ova, M.E. 1976. Forage potential of photoperiod sensitive millet Pennisetum americanum (Linn) K. Schum in southern Nigeria. Nigerian Journal of Animal Production 3:13-19.

AOAC. 2016. Official Methods of Analysis. (20th Edition). Association of official analytical chemists, Washington, DC., USA.

Basavaraj, G., Parthasarathy, Rao. P., Bhagavatula, S. and Wasim, A. 2010. Availability and utilization of pearl millet in India. International Crops Research Institute for the Semi-Arid Tropics (ICRISAT), Patancheru 502 324, Andhra Pradesh, India.

Cecelia, L.F., Amigot, S.L., Gaggiotti, M.L., Rumero, A. and Basilico, J.C. 2007. Global Science, Forage Quality: Techniques for Testing. 123pp.

Comerford, J. 2017. Minerals for beef cows (C) The Pennsylvania State University 2017.

Erarome, M.A. 2005. Nigeria: Country pasture/ forage resources profile, University Press, Oxford. 52pp.

Fiedor, L., Kania, A., Myœliwa-Kurdziel, B., Orze, L. and Stochel, G. 2008. 
Understanding chlorophylls: Central magnesium ion and phenyl as structural determinants. Biochimica et Biophysica Acta (BBA) - Bioenergetics 1777 (12):1491-1500.

Fulkerson, W.J., Horadagoda, A., Neal, J.S., Barchia, I. and Nandra, K.S. 2008. Nutritive value of forage species grown in the warm temperate climate of Australia for dairy cows: Herbs and grain crops. Livestock Science 114:75-83.

Griffing, B. 1956. Concept of general specific combining ability in relation to diallel crossing systems. Australian Journal of Biological Science 9:463-493.

Hanna, W.W. and Cardona, S.T. 2001. Pennisetums and sorghums in an integrated feeding system in the tropics. pp. 193-200. In: Tropical forage plants: Development and us. Rios, A.S. and Pitman, W.D. (Eds.). Boca Raton, Florida, USA: CRC Press.

Hepler, P.K. 2005. Calcium: A central regulator of plant growth and development. Plant Cell 17(8):2142-2155. doi: 10.1105/ tpc.105.032508.

Kevin, K.S. and Blaine, G.S. 1991. Pearl millet forage production in North Dakota. Kevin, K.S. and Blaine, G.S. (Eds.) North Dakota University Press, 19pp.

Khan, Z.I., Ashraf, M., Ahmad, K., Mustafa, I. and Danish, M. 2007. Evaluation of micro-minerals composition of different grasses in relation to livestock requirements Pakistan Journal of Botany 39(3):719-728.

Lang, B. 2001. Millet forage management. IOWA State University, Fact Sheet BL-55.

Little, D.A. 1980. Observations on the phosphorus requirements of cattle for growth. Research in Veterinary Science 28:258-260.

Maiti, R. and Rodriguez, H.G. 2010. Pearl millet: Potential alternative for grain and forage for livestock in semi-arid regions of Mexico International Journal of Bioresource Management 1: 45-47.
Makeri, E.E. and Ugherughe, P.O. 1992. Evaluation of the forage potentials of pearl millet in a semi-arid tropical environment. Journal of Agronomy and Crop Science 169: 319-329.

Maria, M., Rêgo, T., Neuman, J., Neiva, M., do Rêgo, A.C., Cândido, M.J.D., de Sousa Carneiro, M.S. and Lôbo, R.N.B. 2010. Chemical and bromatological characteristics of elephant grass silages containing a mango by-product Revista Brasileira de Zoologia 39(1): 81-87.

Newman, Y., Jennings, E., Vendramini, J. and Blount, A. 2010. Pearl millet (Pennisetum glaucum): Overview and management. SSAGR-337 series, Institute of Food and Agricultural Science.

National Research Council (NRC) 1978. Nutrient requirements of dairy cattle. $5^{\text {th }}$ Edn. National Academy of Sciences: Washington, D.C., USA.

National Research Council (NRC) 1980. Mineral tolerance of domestic animals. Washington, DC, USA: National Academy of Sciences.

Nutrient Requirements of Dairy Cattle, 2016. National Academy of Sciences, National Academy Press, Washington, DC, USA.

Obok, E.E., Aken'Ova, M.E. and Iwo, G.A. 2012. Forage potentials of interspecific hybrids between elephant grass selections and cultivated pearl millet genotypes of Nigerian origin. Journal of Plant Breeding and Crop Science 4(9):136-143.

Ogbaji, M.I. and Aken'Ova, M.E. 1995. Forage yield and quality of three Nigerian pearl millet (Pennisetum glaucum (L.) types and their F1 hybrids. Nigeria Agronomy Journal 28: 91-94.

Rai, K.N., Hash, C.T., Singh, A.K. and Velu, G. 2008. Adaptation and quality traits of a germplasm-derived commercial seed parent of pearl millet. Plant Genetic Resources Newsletter 154:20-24.

Rubanza, C.D.K., Shem, M.N., Bakengesa, S.S., Ichinohe, T. and Fujihara, T. 2005. 
Content of macro and micro minerals of deferred forages in silvo-pastoral traditional fodder banks (Ngitiri) of Meatu district of central north-western Tanzania. Livestock Research for Rural Development 17 (141):9.

Schank, S.C., Diz, D.A. and Smith, R.L. 1993. Nutritive value of regrowth of Pennisetum parents and hybrid progeny. Proc. XVII Intern. Grassl. Cong., Palmerston North, New Zealand. pp. 428-430.

Shahin, M.G., Abdrabou, R.Th., Abdelmoemn, W.R., Hamada and Maha. M. 2013. Response of growth and forage yield of pearl millet (Pennisetum glaucum L.) to nitrogen fertilization rates and cutting height. Annals Agricultural Science 58(2):153-162.
Upadhyaya, H.D., Reddy, K.N. and Sastry, D.V.S.S.R. 2008. Regeneration guidelines: pearl millet. Crop specific regeneration guidelines. Thormann, M.E., Jorge, M.A. and Hanson, J. (Eds.). CGIAR Systemwide Genetic Resource Programme, Rome. 9pp.

Vetriventhan, M., Nirmalakumari, A. and Ganapathy, S. 2008. Heterosis for grain yield components in pearl millet (Pennisetum glaucum L.) R. Br.). World Journal of Agricultural Science 4:657-660.

Wadi, A., Ishii, Y. and Idota, S. 2004. Effects of cutting interval and cutting height on dry matter yield and overwintering ability at the established year in Pennisetum species. Plant Production Science 71:88-96. 